\title{
Preps and Punks: An Inquiry into Externally Imposed Factors that Contribute to the Social Categorization of Students
}

\author{
Georgann Cope Watson \\ Brock University
}

\begin{abstract}
The division of students into social categories is a phenomenon that invites inquiry. Historically, students have tended to migrate towards one of two groups: the preps who embrace all aspects of school life and the punks who reject all aspects of school life. These two groups are reproductions of the social order. This paper inquires into three elements of the discourse of schooling that influence the categorization of students; normalization, the hidden curriculum and the social contract.
\end{abstract}

\section{Résumé}

La division des étudiantes et étudiants en catégories sociales est un phénomène digne d'être exploré. Dans le passé, les étudiantes et étudiants ont eu tendance à s'attacher à l'un de deux groupes, soit les conventionnels «bon-chic-bon-genre » (preppies) qui acceptent tous les aspects de la vie à l'école et les rebelles (punks) qui rejettent tous ces aspects. Ces deux groupes reproduisent l'ordre social. Le texte qui suit examine trois éléments du discours au sujet de l'école qui influencent la catégorisation des étudiantes et des étudiants: la normalisation, le curriculum caché et le contrat social.

Students seem to divide themselves into social categories around the same time they enter into junior high school. An historical examination of this phenomenon reveals that they divide into two main groups: the preps and the punks. The preps are characterized by an interest in their schools; they enthusiastically participate in academic, athletic, and social activities. They are rewarded for this participation by reaping the assumed rewards of academic success; access to higher education, better jobs, and a better life. The punks are characterized by a lack of interest in their schools; they reject academic, athletic, and social activities. They are punished for this rejection by being denied

Georgann Cope Watson is a graduate student in the Masters of Education Program at Brock University, St. Catharines, Ontario, Canada. Her interests are pedagogical practices and teacher education. 
the assumed rewards of academic success. The purpose of this paper is to inquire into this process. I will ask the question: How does the discourse of schooling that resonates throughout education influence the streaming of students into social categories?

Many researchers have examined the division of students into social categories (Bowles \& Gintis, 1976; 2003; Eckert, 1989; Giroux, 2004; Noguera, 2003; Weiner, 2003). Much of this research focuses on socio-economic status as a predeterminant for participation in each of the predominant groups. Although one of the great American myths is centered on the meritocratic ideology of hard work equals great reward, research tells us this is not true (Brookfield, 2000; Giroux, personal communication, March 3, 2004; Weiner, 2003). The facts contradict the narrative in which the self-made person elevates himself above the rest against all odds through their individual efforts. This implies that when we ignore the social and cultural formations, this myth can end up serving repressive interests (Brookfield, 2000, p. 130). It is not always possible to achieve success through determination and hard work. Research suggests that there may be a relationship between pedagogical practices and the social formations that determine academic success (Noguera, 2003). This is the point of inquiry for this paper.

Bowles \& Gintis (1976; 2003), Eckert (1989), Noguera (2003), and Weiner (2003), stress the importance of acknowledging each student's diverse background in order to create an equitable learning environment. They have found that our education system fosters the division of students into social categories. They have determined that the discourse of schooling influences the process that attempts to normalize students. There is a considerable amount of research on the process of normalization: moving students towards one ideal set of characteristics that are measured through performatives such as examinations (Covaleskie, 1993, Foucault, 1975; Kohli, 1999). Noguera (2003) cautions that this process aimed at the division of students begins at a very young age. He suggests that those students who are targeted for exclusion often resemble their adult counterparts who have been excluded from society by imprisonment. Giroux (personal communication, Mar. 3, 2005) agrees. He speaks of the recent movement to initiate policies such as the zero tolerance policy, a policy that has created an entire group of disenfranchised youth. Policies that exclude offending youth from schools contribute to the process of social categorization. Wiener (2003) takes this further when she examines the deficit paradigm: when teachers assume the social factors students bring to school will determine their potential for success. This assumption places youth on predetermined educational trajectories.

A review of the research suggests that schools act as gatekeepers to stream students into social categories. This streaming arises out of the hegemonic ideologies and discourses that direct our system of education. The 
neoliberalist ideology that pervades education supports the production of citizens who are equipped with the skills required by an industrial society to maintain that society's place in the global economy (Giroux, personal communication, March 5, 2005). The discourse surrounding this ideology reinforces the division of students into the division of labour. Eckert (1989) believes that this is the discourse that encourages educators to stream students into one social category (the preps) or the other (the punks).

This paper will look at this problem from a new perspective. It is not only the reproduction of the social order that influences the streaming of students into social categories. This problem is rooted in pedagogical practice that constitutes students into subjects to fit the socially constructed norms that serve our capitalist society (Covaleskie, 1993). Students that do not fit the socio-economic profile are also being placed on inequitable educational trajectories. There is a lack of Canadian research that examines how students from all socio-economic backgrounds are classified into social groups. And there is a lack of Canadian research that connects pedagogical practice to this classification. I believe that the educational discourse resonating throughout our institutions influences the social categorization of all students. And, I believe that discourse exerts pressure on practitioners to act as gatekeepers to better education, better jobs, and better lives.

The first part of this paper will examine the social categories: the preps and the punks. This examination will show how students, educators, and administrators participate in the discourse that perpetuates the division of students into social categories. Second, I will look at the hidden curriculum that is born out of the dominant discourse. I will include a view of the deficit paradigm, a paradigm that influences the hidden curriculum. Next, I will investigate how the social contract of schooling perpetuates the division of students, thus, encouraging practitioners to act as gatekeepers to access and privilege for some and denial for others. Finally, I will reflect on the division of students in an attempt to answer the question of how social categories seem to be embedded in school culture.

\section{Preps and Punks}

Eckert (1989) defines the preps and the punks as the adolescent embodiments of the middle and working class, respectively; their separate cultures are class cultures. According to Eckert they exist in a state of mutual awareness and mutual influence, defining themselves by what the other is not. They cooperate to maintain the hegemony of the class system in the school. Their differences are defined by the acceptance or rejection of the values of the institution; the 
preps participate in the culture of the school and the punks do not participate in the culture of the school. This participation covers all aspects of school life: academics, athletics, and social activities (Eckert, 1989, p. 5).

The predominant explanation for adolescent streaming into one group or the other is that family values have influenced students to make good choices (Weiner, 2003). This implies that students from families who have fostered confidence, ambition and academic skills in their children will gravitate towards the prep group. On the other hand, it is implied that students who gravitate towards the punk group have problems at home. In a study designed to investigate this assumption, Bowles and Gintis (1976) (as cited in Eckert, 1989, p.7) found that the implicit and explicit educational practices in our schools inculcates students into hierarchical social forms. They also found that through inequities in resources and practices in different schools and the unequal treatment of children of varying backgrounds in the same schools, schooling teaches students their place in society. This gradual accumulation of experiences in the early years of schooling leads students to believe that education will bring success (the preps) or that education is a fruitless pursuit (the punks). Twenty-five years later, Bowles and Gintis (2003) revisited their findings and "remain convinced of the truth of the propositions advanced concerning schooling and social structure" (Bowles \& Gintis, 2003, p. 343). Schooling reproduces rather than improves the inequality of a capitalist society. It seems that our educational system, driven by an ideology that views the purpose of education as creating trained and skilled workers who will perpetuate our place in the global economy is responsible for the streaming of students into different social states. This contradicts the "hard work equals great reward" philosophy represented in the media. This is an external influence for students. It implies a hidden curriculum that reinforces inequities for students of diverse backgrounds.

\section{The Hidden Curriculum}

The hidden curriculum is that which is not overtly taught to students. It is also an external influence. It involves the process of normalizing students to a certain set of behaviours that are socially constructed by the hegemonic discourse of education. Through what is hidden, students learn how to conform to the formal and informal rules of the school. Students who conform easily and reproduce the desired behaviours are rewarded. These behaviours include engaged participation in school life; an interest in academic, athletic, and social activities. They are rewarded through promotion into higher education and good jobs. They are the preps. Students who resist the hidden 
curriculum are perceived as deviant, needing discipline and control to promote normalization. They show a lack of interest in school life. They are often excluded and denied access to higher education and good jobs. They are the punks.

Weiner (2003) points out that the deficit paradigm contributes to the hidden curriculum. The deficit paradigm explains a lack of school success as being due to problems in students, their families, their cultures or their communities. Underachievement is viewed as stemming from deficiencies in students; so policies and practices designed to help students succeed attempt to correct their deficiencies. Students entering school are classified into certain economic, cultural, or social formations. Then, consciously or unconsciously, practitioners use the deficit paradigm to stream students into one social category or the other. This supports the theory that a student's experiences accumulate over a number of years resulting in an eventual break from the social norm. "Many students break into one group or the other late in elementary school, when distinct and frequently conflicting sets of needs, interests, and aspirations emerge" (Eckert, 1983, p. 439).

\section{The Social Contract of Schooling}

The social contract of schooling implies that in exchange for an education, students must comply with the authority of the adults in charge. This also implies relinquishing a certain amount of personal freedom. Many students who are frequently excluded from schooling understand these implications, but they have been socially conditioned to accept the educational trajectory they are on, and lose the incentive to adhere to school norms. They realize that the rewards of education, acquisition of knowledge and skills and, ultimately, the admission to college, and access to good paying jobs, are not available to them (Noguera, 2003, Social Control section, para. 3). They resist the forceful process of normalization. Normalization is the manifestation of the dominant ideology. When practitioners believe it is their duty to normalize students into obedient and docile subjects, the hidden curriculum of control and behaviour modification emerges.

Kohli (1999) believes that schools are where students learn what is acceptable and what is not. She points out that the school is one of the central institutions where the self is constituted through its discourse. This is the dubious social contract of schooling. The sooner students accept and understand this relationship, the sooner they will complete the normalization process that comprises the hidden curriculum. Students who reject this relationship will be considered deviant. Deviance means more pressure from the 
school community to accept the social contract. But, if a student decides that school does not work for them, and they internalize the concept that they will not reap the rewards of education, the social contract is broken.

Why would they comply with all the covert rules and regulations of school if the whole process is not geared to meet their needs? Why should we be surprised when they disrupt the educational process? Students understand that the consequences for violating school rules can be severe, but many of them have internalized the labels that have been affixed to them. Thus, when, students decide not to accept the social contract of schooling, the division of students into social categories begins (Noguera, 2003, Social contract section, para. 4).

Once students reject the social contract of schooling, they have internalized the discourse of schooling. This is an important part of this analysis. At about the time of middle school, the educational experiences of students accumulate to the point where they internalize their experiences. Their inability to normalize into the dominant discourse has influenced how they view education and their potential to realize the assumed rewards.

\section{The Division of Students}

So, how does the discourse of schooling influence a student's decision to join the preps or the punks? When the dominant discourse of school culture is rooted in ideology that encourages the division of students into social categories, all aspects of student life are affected. The school reproduces the social forms of society. Consequently, students find themselves experiencing the same social inequities that are prevalent in society. The division of students occurs when the social contract of schooling is broken. The process of division begins at the onset of schooling. It manifests itself in the hidden curriculum that is designed to produce obedient, skilled, and productive subjects. Some students resist this process, perhaps because of the social factors they bring to school with them (socio-economic status, gender, diverse ethnicity, disabilities). Some students will eventually reject the social contract of schooling and they begin to reject the rules and regulations that govern schooling.

This paper has demonstrated that the hegemonic discourse of schooling is a major influence on the social categorization of students. Students cannot change how the policy makers see the purpose of schooling. They cannot resist the hidden curriculum that attempts to mold them into obedient, skilled, and productive subjects ready to take their place in society. They cannot negotiate the social contract of schooling embedded in school culture. But, they can choose to reject the dominant discourse. This choice is 
born out of the external influences of how schooling is viewed in our society. External factors (the purpose of schooling, the hidden curriculum and the social contract) exert pressure on students to normalize. These are factors that materialize through pedagogical practice. But, these factors do not account for student differences; gender, socio-economic status, racial diversity, cultural diversity, and visible and invisible disabilities. It may be impossible for students to overcome these social factors throughout the process of normalization. The negative experiences as they try to normalize accumulate. Then, they decide to reject the dominant discourse. In their adolescent search for identity, they

choose to be punks. I admit that this reflection seems simplistic. But, now I can understand how the punk's experiences have influenced their rejection of the discourse of schooling. And, it is a good starting point for further analysis. It incites an analysis into how the pedagogy of teachers and administrators plays a role in classifying students (Gore, 1997). If practitioners were more aware of how the micro practices that constitute pedagogy influence social formations, can modifications to practice create more equitable learning environments?

\section{References}

Bowles, S., \& Gintis, H. (1976). Schooling in capitalist America. NY: Basic Books.

Bowles, S., \& Gintis, H. (2003). Schooling in capitalist America twenty-five years later. Sociological Forum, 18(4), 343-348.

Brookfield, S. (2000). Education and self directed learning. In C. Matheson \& D. Matheson, (Eds.), Educational issues in the learning age (pp. 129143). London: Wellington House.

Covaleskie, J. F. (1993). Power goes to school: Teachers, students, and discipline. Northern Michigan University: EPS Yearbook. Retrieved November 22, 2002 from http://www.ed.uiuc.edu/EPS/PES-Yearbook/93docs/COVALESK.HTML

Eckert, P. (1983). Beyond the statistics of adolescent smoking. American Journal of Public Health, 43(4), 439-441.

Eckert, P. (1989). Jocks and burnouts. NY: Teachers College Press.

Foucault, M. (1975). Discipline and punishment. NY: Random House.

Giroux, H. A. (2004). The abandoned generation: Democracy beyond the culture offear. NY: Palgrave Macmillan.

Gore, J. (1997). Power relations in pedagogy: An empirical study based on Foucauldian thought. In C. O'Farrell, (Ed.) Foucault: The legacy (pp. 651-653). Brisbane, AUS: Queensland University of Technology. 
Kohli, W. (1999). Performativity and pedagogy: The making of educational subjects. Philosophy and Education, 18, 319-326.

Noguera, P. A. (2003). Schools, prisons, and social implications of punishment: Rethinking disciplinary practices. Theory into Practice, 42(4) 341-351.

Ozmon, H., \& Craver, S. (1995). Philosophical foundations of education ( $5^{\text {th }}$ ed.). NJ: Prentice Hall.

Weiner, L. (2003). Why is classroom management so vexing to urban teachers? Theory into Practice, 42(4), 302-313. 